University of Ankara, Faculty of Veterinary

Science, Department of Protozoology, Medical Arthropodology and

Control of Parasitic Diseases

Prof. Dr. Mihri Mimioğlu

\title{
SOME OBSERVATIONS ON RHINOESTRUS \\ PURPUREUS INFESTATION OF HORSES IN TURKEY AND ITS CONTROL WITH NEGUVON
}

\section{By}

\section{Fahri Sayin*}

\section{Introd uction}

In our studies on Gastrophilus species and their control in Turkey, we observcd that some horses treated with Neguvon expclled larvae of Rhinoestrus purpurcus (nasal bot of horsc) in their feces. Thus we found the opportunity to study partly the prevalance of this parasite and its control with Neguvon. This is a preliminary report on Rhinoestrus purpurcus infestation and the promising effect of Neguvon for its control.

Rhinoestrus purpurcus and its larva from horses was found in Austria and described by Braucr (2) for the first time. The classic paper on the morphology, biology and pathogenesis was written by Portschinsky (20). The studics on the horse nasal bot have since been continued by Russian authors, especially with respect to their veterinary and medical importance. A good review of the studies with respect to the morphology, biology, pathogenecity and distribution of Rhinoestrus purpureus was made recently by Zumpt (29).

Rhinocstrus purpurcus was originally Palaearctic species but it has, together with the horse, reached several parts of the Ethiopion and the oriental regions. This species is not found in Nearctic and Australasian regions (29). In a survey made in Russia (Bachkiriya) I 2.2 per cent of horses were found to be infested with horsc nasal

* Associate Professor, Veterinary Faculty, Department of Protozoology, Medical Arthropodology and Control of Parasitic Diseases, Ankara - Turkey. 
bots ( $\mathrm{I}$ ). On the other hand in Africa (Chat) 20.89 per cent of donkeys wcre found to be carrying them (9). This parasite has also occurred in France, Italy, Spain and Algeria $(3,16)$. Its presence in Turkey was already recorded, but the zone where the parasite occurred was not indicated $(18,10,28)$. The data with respect to its incidense and economic importance for Turkey are also not available.

The normal hosts of Rhinoestrus purpureus arc horse, donkey and their hybrids $(\mathrm{I}, 1 \mathrm{I}, 8,21,9,29,18,27,16,3,7)$. Also some records of the infestation of man in some parts of the world have been confirmed $(10,4,12,29,20)$.

In horses, the larvae are found in the throat regions, at the base of the tongue, in the nasal and pharyngial cavities and cause pathological changes and death of the animals $(1,11,7,29)$. In men they are found in eyes and create ocular myiasis $(20,12,4)$.

Nothing much about the control of nasal bots in horses werc known up to the present time. However introduction into nasal cavity of $3 \%$ cmulsion of the preparation $\mathrm{C}-20$ ( $20 \%$ Hexochlorone) or of a mixture of Carbone disulfide, lysol and water is recommended to destroy them (13). As far as we know, organophosphorus compounds have not been tested yet to treat horses for this parasite. Neguvon was already found to be effective on nostril bots in sheep when it was administered orally or was introduced into nasal cavity ( 14,17 , $22,23,24,25,6,5,26,19)$.

\section{Material and Method}

The animals examined for the larvae of Rhinoestrus purpurcus were from the central (Ankara, Eskişchir, Konya), southern (Adana), eastern (Sivas, Malatya, Diyarbakır), western (Bursa, Manisa) and northern (Samsun) parts of Turkey. The animals from south-western (Muğla) and north-western (Tekirdağ) parts were also investigated.

The study was carried out on a total of 1963 equines ( $168_{3}$ horses, 265 donkeys and 15 mules). The animals were fed with Neguvon to obtain the larvae from their feces or nasal discharges. Some of the animals were necropsied to search larvac in their alimentary tracts or nasal cavities after treatment with Neguvon. Neguvon was given to the animals in feed at the rate of $35 \mathrm{mgs}$. per $\mathrm{kg}$. of body weight after 12 hour starvation. $10 \%$ solution of Neguvon in water 
was mixed with feed and animals were fed with it. The treated animals were kept under observation in a stable for one week. During this period the entire feces excreted and nasal discharge obtained from some of the animals were investigated for expelled bots. The alimentary tracts or nasal cavities of the animals which were killed after treatment were opened and examined for the larvae.

The larvac obtained from horses were placed in a jar containing $70 \%$ alcohol and brought to the laboratory for identification. They were studicd under steorozoom microscope.

\section{Res u l t s}

During the period from July 1964 to June 1967 a total of 1963 equines (1683 horses, 265 donkeys and ${ }_{15} 5$ mules) werc treated with Neguvon for the larvae of Rhinoestrus purpurcus. They were 8 months to 1 I year old. Of 1683 horses, io $(0,59 \%)$ expelled a total of 23 larvac in their feces. Most of the larvac were eliminated with the feces between 24 and 72 hours after treatment. Few of them wcre passed out between 10 and 24 or 72 and 96 hours. All the larvae were in their third stage. The number of larvae which werc expelled by each treated animal varied from 1 to 5 . Following application of Neguvon, the first larva appcared in the feces after Io hours had elapsed and the last one 96 hours post medication. The larvae expelled in feces were dead and nearly digestcd. The horses infested with Rhinocstrus purpureus werc from Samsun and Adana provinces. They were 6 to ro years old and did not show any climical sign with respect to Rhinoestrus purpureus infestation.

Neither donkeys nor mules treated with Neguvon excreted horse nasal bots, although some of them were from Adana. On the other hand the bots have not been found in alimentary tracts and nasal cavitics of 12 horses and 14 donkeys killed 6 to I 4 days following the treatment. These animals came from Adana and Samsun, and they did not show any sign of infestation before necropsy performed. Any of $\mathrm{o}$ o horses infested with horse nasal bots could not be killed following treatment and exact test results were not obtained post mortem.

The description of morphological characters with respect to



The length of the larvae vary from 16 to $25 \mathrm{~mm}$. They show rows of spines on both the dorsal and ventral sides of the segments. 
The second segment has denticles dorsally and ventrally, the third and forth segments bear two to three complete rows dorsally, and more or less medially interruptcd ones on the fifth and sixth segments. The two following ones have only lateral groups, and on the ninth to the twelfth segments, dorsal spines at the anterior margins are absent. The eleventh segment, however shows four to five rows of anteriorly directed spines at the hind margin. On the ventral surface there are three to four rows at the anterior margins of the third to the twelfth segments. In addition to this, groups of large denticles are found on the postcrior margins of the latero-ventral swellings. Both anal bulges have spines. The posterior peritrems are open (Figure: 1 ).

\section{Discussion and Conclusion}

The presence of Rhinoestrus purpureus infestation of horses in Turkey was recorded in a textbook (I8), but no reference with respect to the prevalence of this parasite and the zone where it occurred are available. Thus this report should be regarded as a preliminary document. And the subject should be investigated largely by different methods to obtain the bots from cquine and to get exact results con nected with the prcvalcnce and incidence of Rhinoestrus purpureus. We beleive that this parasite is common in Turkey, as in Russia andin some African countrics.

As we know, few investigations were made for the control of Rhinoestrus purpureus infestation of horses up to present time. For instance Hexochlorene and Carbon disulfide were tested and they were found effective on horse nasal bots when infected into nasal cavity (13). But, reference with respect to effect of organophosphorus compounds on this parasite is not available, However it is confirmed that Neguvon has a hingh value for the control of nostril bots in sheep when it is applicd orally in feed or injected into nasal cavity ( 14,17 , $22,23,24,25,6,5,26)$. The result obtained from our investigation shows that Neguvon also promises an effect on horse nasal bots when it is fed in feed at the ratc of 35 miligrams per $\mathrm{kg}$. of body weight. But in this trial the horses which were treated and expelled larvac of Rhinoestrus purpureus were not killed and exact test results could not be obtained. Therefore it is not possible here to give a ratio for the effectiveness of Neguvon on the horse nasal bot and to discuss the effect of Neguvon on the parasite in different organs. Further studies should be conducted to enlighten the subject. 


\section{S u m m a r y}

During the period from July 1964 to June 1967 a total of 1963 equincs ( 1683 horses, 265 donkeys and 15 mules) ware treated with Neguvon for the larvae of Rhinoestrus purpureus. Neguvon was administered to the animals in fecd at the rate of $35 \mathrm{mgs}$. per $\mathrm{kg}$. of body weight after 12 hour starvation. Of 1683 horses, $10(0,59 \%)$ expclled a total of 23 larvac in their feccs. The horses infested with Rhinocstrus purpureus were from Adana and Samsun provinces of Turkey. Neither donkeys nor mules treated with Neguvon excreted horse nasal bots, although some of them came from Adana. The larvac collected from the feces of the horses treated with Neguvon are described and the results obtained from the treatment are recorded in the paper.

\section{O z et}

\section{Atlarda Rhinoestrus purporeus Enfestasyonu ve Neguvon ile Tedavisi}

I 964 ve 1967 yılları arasinda memlekctimizdeki atlarda bulunan Gastrophilus larvalarının tedavisi üzerinde çalışırken, Neguvon verilen bazı atların dışkısında Rhinocstrus purpureus larvalarına rastlanmıştır. Bu husus bizi, Neguvon'un bu parazit üzerine olan etkisi yönünden, araştırmaya sevketmiştir. Dolayısiyle Rhinocstrus purpurcus'un momleketimizin ncresinde ne nisbette bulunduğunu, kısmen de olsa, tesbit etmek mümkün olmuştur. Neguvon verilen hayvanlar Ankara, Eskişehir, Konya, Adana, Sivas, Malatya, Diyarbakır, Bursa, Manisa, Muğla, Samsun vc Tekirdağ bölgelerine aittirler. Genel olarak 1963 hayvan ( 1683 at, 265 merkcp ve ${ }_{5} 5$ katır) ilâçlanmış ve bunlardan sadece ro $(\% \quad 0,59)$ atın dışısında Rhinoestrus purpureus larvalarına rastlanmıstır. Enfeste atların tamamen Samsun ve Adana bölgesine ait olduğu tesbit edilmiştir. Merkep ve katırlar arasında enfeste olan görülmemiştir.

Neguvon, $35 \mathrm{mgr} / \mathrm{kg}$. nisbetinde, hayvanlara verilmiştir. Bunun suda \% ı'luk solüsyonu yapılmış, sonra yeme katılarak hayvanlara ycdirilmiştir. İlâçlanan hayvanlar akşamdan aç bırakılmış ve ycmle birlikte sabahleyin ilâç verilmiştir. Hayvanlar jlâçlandıktan sonra I hafta süreyle ahırda bırakılmıs ve bu müddet zarfinda dışkıle larvaların dökülüp dökülmediği kontrol edilmiştir. Neguvon'un 
Rhinoestrus purpureus larvalarına tesir ettiği ve bu parazitin mücadelesinde kullanılabileceği, bu çalışma ile anlaşılmıştır. Yalnız ne nisbette tesirli olduğunu ortaya koymak için daha fazla çalı̧maya ihtiyaç vardır; zira bu çalı̧̧mada, tedavi neticesi, larva düşüren atlardan hiç birisi öldürülememiş ve denemenin neticesi tam olarak kontrol edilememiştir.

Genel olarak 23 adet, 3 üncü devirde bulunan, larva toplanmıştır. Bunların uzunluğu ı 6 ile $25 \mathrm{~mm}$. arasındadır. Halkalarının dorsal ve ventral yüzlerinde diken siraları vardır. 2 inci segment'in dorsal ve ventral yüzünde dişcikler mevcuttur. 3 üncü ve 4 üncü segment'in dorsal yüzünde fasılasız 2-3 sıra diken bulunur. 5 ilâ 6 ncı segment'te diken sıraları fasılalıdır. Bundan sonraki 2 segment'in iki yanında diken grupları mevcuttur. 9, I0, I I ve i 2 inci segment'in dorsal yüzünün ön kısminda diken yoktur. I I inci segment'in arka kenarinda 5 sira diken bulunur. 3'den I 2'ye kadar olan segmentlerin ventral yüzünde, ön kenarlarında 3-5 sıra diken vardır. Buna ilâveten latero-ventral şişliklerde büyük diken grupları bulunur. Her iki anal şişlikde de diken mevcuttur. Arkadaki hava delikleri (posterior pcritrems) açıktır (Sekil: I).
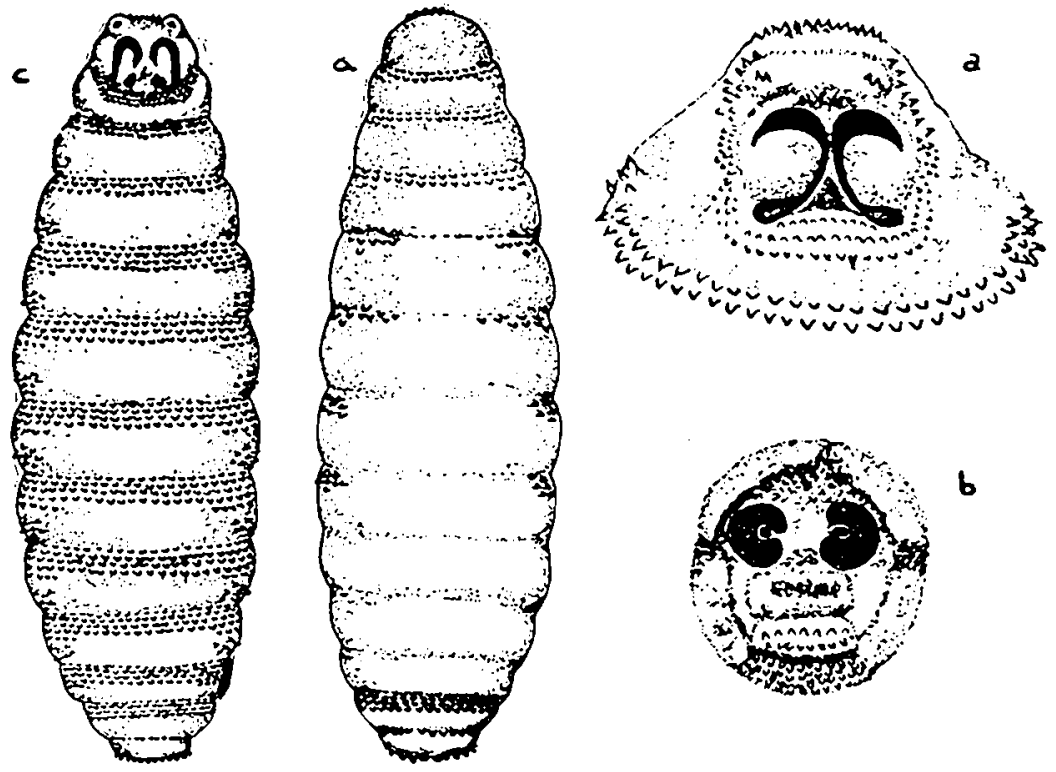

Fig.: 1. Third larval stage of Rhinocstrus purpureus (Brauer): a - head in ventral view, $\mathbf{b}$ - posterior peritrems, $\mathbf{c}$-third larval stage in ventral view, $\mathrm{d}$ - third larval stage in dorsal view. 


\section{References}

I- Akchurin, B. S. (1945): Rhinoestrosis in horses in the Bashkir $A S S R$. Veterinariya 22:2 I.

2- Brauer, F. (1886): Rhinoestrus purpureus. Wicn Ent. ztg. 5:289.

3- Brumpt, E. (1949): Précis de parasitologie I, II., Masson ct Cie, Paris.

4- Chams, G. and Mohsenine, H. (1956): Une des cas myiase ophtalmique par la larva de $R$. purpureus. Acta vet. Med. Iran, I:22.

5- Chavorria, Ch. M. and Corillo, R. A. (1959): Eine neartige wirksame Behandlung der durch Oestrus ovis linn. ausgelösten Myiasis cavitaria. zbl.vet. Med. 6,816-824.

6- Drummond, R. O. ( 1962$)$ : Control of larvae of oestrus ovis in sheep with systemic insecticides. J. parasit. 48:2 I I-2 I 4 .

7- Ershow, V. S. (1956): Parasitology and parasitic disease of Livestock. State publishing House for Agricultural Literature, Moscow.

8- Grunin, K. Ya. (1957): Botflies (Oestridae), Fauna U.R.S.S. Insecta: Diptera, I9, No: 3 .

9- Graber, M. and Gruvel, J. (1964): The causal agents of Myiasis in domestic and wild animals of equatorial Africa. Revue Elev. Med. Vet.Pays.Trop. I 7 .

10- Hakkn, H. (193I): Rhinoestrus purpureus'ün husule getirdiği bir oculomyiase vak'ası. T'ürk oftalm. Gaz. I (I I-I2): 721-723.

I I- Karpenko, S. E. (1947): Rhinoestrosis of horses. Veterinariya $24: 4^{2}$.

12- Krümmel, H. and Brauns, A. (1956): Myiasis des Auges. Mediziniche und Entomologische Grundlagen. Z. Ongew Zoologic $43: 129$.

I3- Kolomiets, Y. S. (1954): Rhinoestrus purpureus infestation in horses and its control. Rep. Inst. Sovict. Conf. Vet. Derm. Moscow: i 86-188.

I 4- Knopp, F. W. and Drudge, J. H. (1964): Efficacy of several organic phosphates against the botfly of sheep. A.m. J. Vet. Res. 25: I686-1689.

I5- Mimioğlu, M. (1959): Genel ve Özel Tibb Artropodoloji. Veteriner Fakültesi Yayınları: I I I. Ankara. 
16- Neveu-Lemaire, M. (1938): Traité d'Entomologie Medical et Veterinaire. Vigot Fréres, Paris.

I 7 - Negru, D. and May, I. ( 1964 ): Biology, Epidomiology and experimental therapy of Oestrus ovis infestation. Rev. Zothech. Med. Vet. Bucuresti I 4, No.10, I 7-77.

I8- Oytun, H. (1956): Tibb Entomoloji. A.U. Tıp Fakültesi Yayınlarindan 49, Ankara.

I9- Petrov, D. and Bratanov, V. ( 1963$)$ : Oestrus ovis infestation of sheep in Bulgaria and control with Trichlorphon. Izv.Vet.Inst.Zaraz. Parasit. Bolsti, Sofia 9, I63-1 70.

20- Portschinsky, I. A. ( 19 I $_{5}$ ): Rhinoestrus purpureus Br., a parasite of the horse infecting its larvae into the eyes of man. Men Burea Entomology Sci. Comm. Cent. Board of Land Adm. Agric. Petrograd VI, No: 6 .

2I- Rodhain, J. and Bequaert, J. (I9I6): Materiaux pour une étude monographique des diptéres parasite de l'Afrique II. Revision des oestrinae du continent African. Bull. sci. Fr. Bclge. 50:53.

22- Schrag, L. ( 1964 ): Field trials with the preparation Dylox for efficacy against larvae of $O$. ovis $L$. under south African conditions. Vet. Med.Rev. Leverkusen, I. 32-39.

23-Schrag, L. (I 964): Field tests with Dylox (Trichlorphon)against O.ovis in sheep in south Africa. Vet. Med. Nachr. No: 2: 97-104.

24- Semenov, P. V. (1962): Treatment of oestrus ovis infection in sheep by injection of dimethoate or Trichlorphon into the frontal sinuses. Veterinariya, Moscow, 4: 33-34.

25- Semenov, P. V. ( 1964$):$ New drugs and methods for preventing and treating sheep nostril fly infestation. In "problemy veterinarnoi sanitrii" 262-268, N.F. Rostrovtseva, Moscow.

26- Stampa, S., pols, J. W. ( I 960) : Field test mit dem praparat Neguvon $A$ auf wirksamkeit gegen die Maden der $\mathcal{N}$ asenbremse des Schafes (Oestrus ovis L) unter Südafrikanischen Verhältnissen. Vet. Med. Nachr. 239.

27-Unat, E. K. (I959): Tibbî parazitoloji. Ist. U.Tip Fak. yayını $847 / 39$, Istanbul.

28- Unat, E.K., Yaşarol, Ş., Merdivenci, A. (1965): Türkiye'nin parazitolojik coğrafyası. Ege Üniversitesi Tıp Fak. Yayını No: 42 .

29- Zumpt, F. ( $\left.9^{6} 6_{5}\right)$ : Myiasis in man and animals in the old world. Butterworths, 